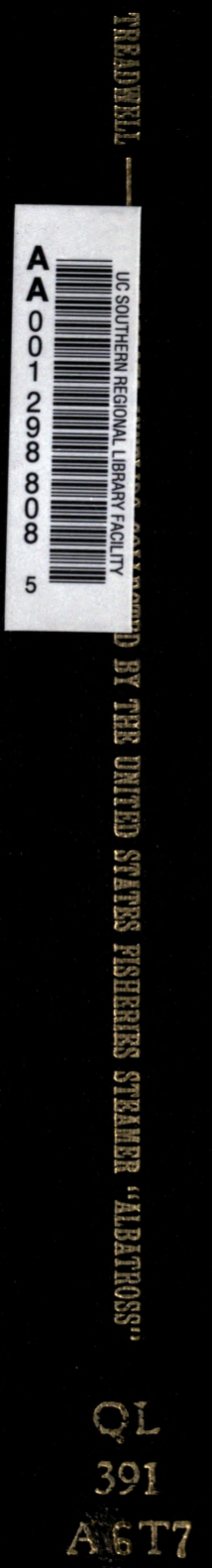


is

78 
UNITED STATES NATIONAL MUSEUM

\section{Bulletin 100}

VOLUME 1, PART 8

CONTRIBUTIONS TO THE BIOLOGY OF THE

PHILIPPINE ARCHIPELAGO AND

ADJACENT REGIONS

\section{POLYCHAETOUS ANNELIDS COLLECTED}

BY THE UNITED STATES FISHERIES

STEAMER “ALBATROSS" IN THE

WATERS ADJACENT TO THE

PHILIPPINE ISLANDS IN

1907-1910

By A. L. TREADWELL

Of the Department of Zoology, Vassar College

Poughkeepsie, New York

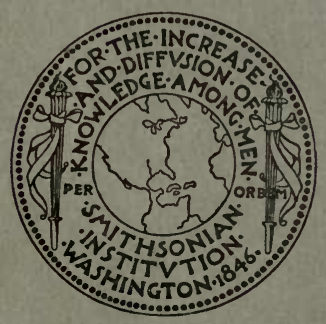

WASHINGTON

GOVERNMENT PRINTING OFFICE 



\section{Bulletin 100 \\ VOLUME 1, PART 8}

CONTRIBUTIONS TO THE BIOLOGY OF THE PHILIPPINE ARCHIPELAGO AND

ADJACENT REGIONS

\section{POLYCHAETOUS ANNELIDS COLLECTED} BY THE UNITED STATES FISHERIES STEAMER “ALBATROSS" IN THE WATERS ADJACENT TO THE PHILIPPINE ISLANDS IN 1907-1910

By A. L. TREADWELL

Of the Department of Zoology, Vassar College Poughkeepsie, New York

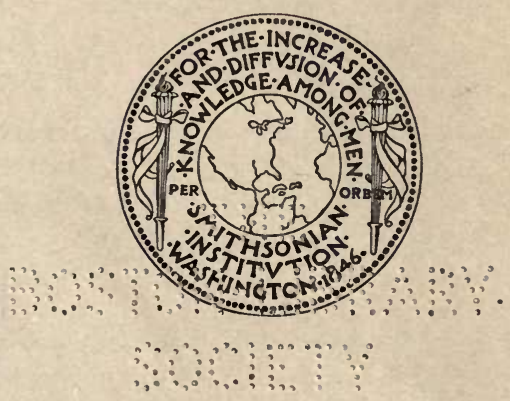

WASHINGTON GOVERNMENT PRINTING OFFICE 1920 


$$
\begin{aligned}
& \because \because
\end{aligned}
$$

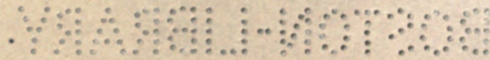

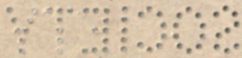


POLYCHAETOUS ANNELIDS COLLECTED BY THE UNITED STATES FISHERIES STEAMER "ALBATROSS" IN THE WATERS ADJACENT TO THE PHILIPPINE ISLANDS IN 1907-1910.

By A. L. Treadwell,

Of the Department of Zoology, Vassar College, Poughkeepsie, New York.

\section{INTRODUCTION.}

Some time ago the polychaetous annelid collections made by the United States Bureau of Fisheries Steamer Albatross in the Philippines were sent me for description. As a result of a preliminary study the old species were identified and sent to the United States National Museum some two years ago. Two new species were also described, but since pressure of other duties prevented my continuing the work the remainder of the collection was turned over to my assistant, Miss Ruth Hoagland, whose report follows this. A few old species which I had overlooked are included in her report. These two papers together, then, comprise the report on the polychaetous annelids of this expedition.

\section{DESCRIPTION OF SPECIES.}

\section{Family SYLLIDAE.}

\section{Genus AUTOLYTUS Grube.}

\section{AUTOLYTUS TRIANGULIFER Grube.}

A utolytus triangulifer GRUBE, 1878 , p. 132, pl. 7 , fig. 8 .

The polybostricous stage was collected in considerable numbers at San Miguel Harbor, Ticao Island. Grube reported that his specimens were incomplete. One specimen in this collection had in the posterior region 31 somites similar in structure, though narrowing very noticeably toward the posterior end. These somites are largely covered by the prominent parapodia. Somites 32, 33, 34, 49, 50, and 51 of the entire body have small parapodia and are covered dorsally with a brownish pigment, an expansion of the median pigment spots occurring in the anterior somites. Behind somite 44 was a colorless region containing about six somites with very small para- 
podia and a pygidium carrying a pair of anal cirri. They were too poorly preserved to determine the precise number of somites involved.

\section{Genus SYLLIS Savigny.}

SYLLIS (ODONTOSYLLS) HYALINA Grube.

Syllis (Odontosyllis) hyalina Grure, 1S78, 1). 129, pl. 7, flg. 1.

Collected at San Miguel Harbor, Ticao Island.

Family AMPHINOMIDAE.

Genus CHLOEIA Savigny.

Chloeia CEYLONicA Grube.

Chloeia ceylonica Grube, 1878, p. 10.

In this paper Grube refers to an earlier paper ${ }^{1}$ which was not accessible to me, but the comparison which he there draws between C. ceylonica and $C$. flava makes it certain that this is his species.

Collected at Jolo Anchorage, Jolo.

\section{Chloeia flava Pallas.}

Aphrodita flava Pallas, 1766, p. 97, pl. 8, figs. 7-11.

Chloeia flava McIntosh, 1855, p. 8, pl. 3, figs. 1 and 3, pl. 1a, figs. 7-9.

Collected at Port Dupon, Leyte Sound; Anchorage, Tomindos Sound; D 5561, Teomabal Island, Jolo, 10 fathoms. D 5165, Observation Island, Tawi Tawi Group, 9 fathoms, coral bottom.

\section{Genus EURYTHOE Kinberg.}

EURYTHOE PACIFICA Kinberg.

Eurythoe pacifica Kinberg, 1857, p. 14.-Grube, 1878, p. 6.-McINTosh, 1885 , p. 27 , pl. 2 , figs. 3,4 ; pl. 3 , fig. 3 ; pl. $2 a$, fig. 13 ; pl. $3 a$, figs. $5-9$.

Collected at Nau Wau, Formosa; Batan Island; Tataan, Tawi Tawi, San Pascual, Burias Island. A fragment, probably of this species, was collected at Nasugbu, Luzon.

\section{Family APHRODITIDAE.}

\section{Genus POLYNOE Savigny.}

POLYNOE MIRABILIS MeIntosh.

Polynoe mirabilis McIntosn, 1885, p. 121, pl. 16, fig. 1; pl. 12a, figs. 9-11.Trfadwell, 1906, p. 1149.

As stated in my original paper, McIntosh's specimen was undoubtedly incomplete and had originally more somites than he described. These from the Philippines were approximately $70 \mathrm{~mm}$. long and 15 $\mathrm{mm}$. broad at the broadest part, thus much larger than the Chal- 
lenger specimens. No elytra remained and the head in each was badly preserved, so that it was impossible to be certain as to their normal form. In all cases the head had been rolled over so that the basal joint of the median antenna had been directly posteriorly. Some of the few remaining cirri showed a violet color and the inner surface of the proboscis is a dark color, as described by McIntosh.

Collected from D5122, Malabrigo Light, East coast of Mindoro, N. $46^{\circ}$ W., 20.60 miles $\left(13^{\circ} 21^{\prime} 30^{\prime \prime}\right.$ N.; $120^{\circ} 30^{\prime} 33^{\prime \prime}$ E.) 220 fathoms, green mud bottom. D5114, Sombrero Island, Balayan Bay, N. $36^{\circ}$ E., 7.2 miles $\left(13^{\circ} 36^{\prime} 11^{\prime \prime}\right.$ N.; $120^{\circ} 45^{\prime} 26^{\prime \prime}$ E.) 340 fathoms, fine sand bottom.

\section{POLYNOE OCELlata McIntosh.}

Polynoe ocellata McIntosh, 1855, p. 126, pl. 12, fig. 3 ; pl. $12 a$.

A few were found at Dร382, Arena Point, Luzon, S. 55 W., 3.8 miles $\left(13^{\circ} 15^{\prime} 20^{\prime \prime}\right.$ N.; $122^{\circ} 45^{\prime} 30^{\prime \prime}$ E.), 128 fathoms, mud bottom, in tubes which were apparently made by Phyllochaetopterus claperedii, though none of the animals were to be found, and they may have been made by some other member of this family. None of the Polynoes were well preserved, but enough remained to establish their identity.

\section{Genus APHRODITA Linnaeus.}

\section{APHRODITA ECHIDNA Quatrefages.}

Aphrodita echidna Quatrefages, 1865, p. 197.-McIntosh, 1885, p. 36, pl. 7, figs. $1-2$; pl. $6 a$, figs. $2,3$.

Collected at D5123, Malabrigo Light, East coast of Mindoro, N. $44^{\circ}$ W., 32.50 miles ( $13^{\circ} 12^{\prime} 45^{\prime \prime}$ N.; $121^{\circ} 38^{\prime} 45^{\prime \prime}$ E. $), 283$ fathoms, green mud bottom.

\section{Genus IPHIONE Kinberg.}

\section{IPHIONE CIMEX Quatrefages.}

Iphione cimex QUATREFAgES, 1865, p. 270.

Iphionella cimex IICIntosH, 1885 , p. 58, pl. 9, figs. 4-6; pl: 18, fig. 3 ; pl. $8 a$, figs. $7,8$.

McIntosh proposed a new generic name for this form, but did not define his generic characters. The specimen agreed with his description except that he saw no antennae. No median antenna was preserved, but there were two lateral antennae with rather long, dark-colored basal portions nearly twice as long as the head, each having a filamentous tip longer than the basal portion. On each elytrophore, underneath the elytron, is a thin translucent plate like a shadow of the elytron.

McIntosh stated that the ventral setae are more prominent than the dorsal ones. In this specimen the dense tuft of slender serrated - dorsal setae entirely obscures the stouter ventral one. 
Collected at Tataan, Simaluc shore, station D5250, Linao Point, Gulf of Davao, 23 fathoms, coral and sand bottom.

\section{Genus PALMYRA Savigny. \\ PALMYRA AURIFERA Savigny.}

Palmyra aurifera Savigny, 1820, p. 17.-AUdourn Axd Mul.Ne Edwards, 1832-1834, p. 110, pl. 2n, figs 1-6.-Grube, 1878, p. 13.-McIstosh, 1855, p. 53, pl. 9 , figs. 1,$2 ; \mathrm{pl} .6 a$, figs. 8,9 .

I have doubtfully identified this species. Grube gave out no figures and the head is much larger and more distinct than Audouin and Milne Edwards's figure. It agreed in general with the description of McIntosh, though much larger, measuring about $30 \mathrm{~mm}$. in length by 8 in breadth.

Collected at station D5250, Linao Point, Gulf of Davao, 23 fathoms, coral and sand bottom.

\section{Genus EULEPETHUS Chamberlin.}

EULEPETHUS HAMIFERA Grube.

Eulepis hamifera GruBE, 1878, p. 52, pl. 3, fig. 8 .

Collected at station D5235, Nagubat Island, Mindanao, 44 fathoms, soft mud bottom.

\section{Genus PSAMMOLYCE Kinberg.}

PSAMMOLYCE FIJIENSIS McIntosh.

Psammolyce fijiensis McIntosh, 1885, p. 149, pl. 21, fig. 6; pl. 22, fig. 4; pl. 24 , fig. 6 ; pl. $13 a$, fig. 18 .

One incomplete specimen from station D5160, Tinakta Island, . Tawi Tawi Group, 12 fathoms, sand bottom.

\section{Genus STHENELAIS Kinberg.}

STHENELAIS LUXURIOSA Grube.

Sthenclais luxuriosa GrUBe, 1878, p. 54.

Collected at station D5375, Tayabas Light (outer), 107 fathoms, green mud bottom; D5423, Cagayan Island, Jolo Sea, 508 fathoms, gray mud, coral sand bottom; D5397, Panalangan Point, between Samar and Masbate, 134 fathoms, green mud bottom; D5257, Utara Point, Bongo Island, eastern Illana Bay, Mindanao, 28 fathoms, mud bottom; D5183, Lusaran Light, between Panay and Negros, 96 fathoms, soft green mud bottom; and D5392, Tubig Point, Samar, 135 fathoms, green mud and sand bottom.

Fragments of members of this family were collected at stations D5297, Matcot Point, China Sea, 198 fathoms, mud and sand bottom; and D5108, Corregidor Light, China Sea, 13 fathoms, coral bottom, but were too much injured for identification. 


\section{Family PHYLLODOCIDAE.}

\section{Genus PHYLLODOCE Savigny.}

PHYLLODOCE DUPLEX McIntosh.

Phyllodoce duplex McIntosh, 1885, p. 167, pl. 27, fig. 8; pl. 32, fig. 9; pl. $15 a$, fig. 1.

Collected at station D5113, Sombrero Island, Balayan Bay, 159 fathoms, dark green mud bottom.

\section{Genus MYSTA Malmgren.}

\section{MYSTA MACULATA, new species.}

A single specimen, with a length of approximately $60 \mathrm{~mm}$. Width of head between tentacles, $0.5 \mathrm{~mm}$; width at somite $20,1.5 \mathrm{~mm}$. There were about 146 somites present, the posterior end having been lost. Anteriorly the proportion of length of somite to breadth is as 1 to 8 , and the dorsal cirri are inconspicuous. Beginning with approximately the fortieth somite there is a gradual change in the proportion of length to breadth, and toward the posterior end this proportion is about as 1 to 2 . Anteriorly the dorsal cirri are very inconspicuous, and while they overlap one another to a certain extent they cover no part of the somite surface. Posteriorly these cirri become much more prominent, but still do not overlap the body. Each dorsal cirrus is marked with a median dark spot, rather faint anteriorly but very prominent posteriorly. The general body color (in alcohol) is a very light brown, marked on the dorsal surface with dark spots, which in the anterior somites show

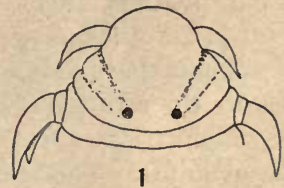

1
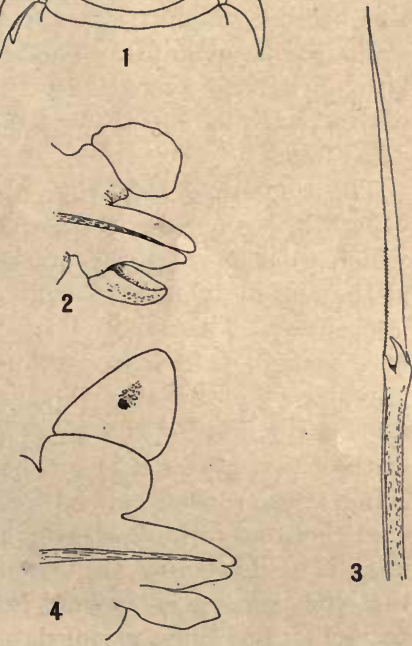

Figs. 1-4.- Mysta maculata, 1, Head $\times$ $20 ; 2,15$ TH PARAPODIUM $\times 45 ; 3$, COMpound seta $\times 295 ; 4$, Parapodium FROM MIDDLE REGION $\times 45$.

a tendency to arrange themselves in a transverse row near the anterior border of the somite. Ventrally the body has a broad median dark band, spotted with white.

The prostomium (fig. 1) is, roughly speaking, lens-shaped, with the long diameter transverse, this long diameter being about onefourth longer than the antero-posterior one. About one-quarter of 
its length from either end the anterior border is excavated for the attachment of a tentacle. These are shorter than the head, rather thick, and taper rapidly to a sharp point. Two other tentacles are attached to the ventral surface of the head and are not visible from above. These are similar to the dorsal tentacles in form, but are heavier. One pair of small eyes lies near the anterior border. Just posterior to the right hand one of these is a dark spot which resembles an eye, but is, I think, merely a surface marking. Two tentacular cirri on either side are attached to the first somite. They are much like the tentacles in form, but about twice as large. The mouth is bounded anteriorly by the prostomium, while about onethird of the posterior border is made up of an anterior prolongation from somite 2.

The first parapodium is about two-thirds as long as the second, but is similar to it in all other respects.

A well-developed parapodium (fig. 2-an anterior view of the fifteenth) shows the setigerous portion prolonged into bifid presetal lip, behind which arises a row of about 25 compound setae with elongated basal joints. The notocirrus is broadly rounded and carried on a large cirrophore. The neurocirrus is bluntly conical in outline, with its dorsal surface next the setigerous lobe rather deeply excavated.

The compound seta (fig. 3) has the basal portion very slightly curved, the convex side apparently with a narrow transparent edge, which thickens abruptly at the apex. The apex has a sharp hook at the end of the convex surface, with a much heavier curved hook opposite it. This larger hook lies a little inside the line of the concave margin, which is continued into a much smaller spine. Apparently other smaller spines of uncertain arrangement are located around the base of the large hook. The terminal portion is broad at the base and tapers to a sharp point, the whole terminal portion being about as long as the free part of the basal portion. Near its base there are minute denticulations along its thinner edge. I was unable to determine the extent of these denticulations, but think that they do not go beyond the middle of the joint. With careful focussing, fine lines, giving it a shagreen appearance, may be seen on the surface of this terminal joint.

A later parapodium (fig. 4) shows a cirrophore larger than the cirrus, and there is a black spot in the center of the cirrus. In the preparation the whole cirrus was bent away from the observer so that the cirrus was really larger than appears in the figure. The setae in these parapodia are similar to those farther forward.

Collected at station D5146, Sulade Island, vicinity of Siasi, 24 fathoms, coral sand and shell bottom.

Type.-Cat. No. 18940, U.S.N.M. 


\section{Family NEREIDAE.}

The collection contained large numbers of heteronereis stages of Nereis. Since during this phase the bodily changes are such as to obscure speeific characters I have relied almost entirely in determining species on the characters of the jaws and paragnaths. These determinations must therefore be regarded as provisional.

\section{Genus NEREIS Linnaeus.}

\section{NEREIS MASOLOCENSIS Grube.}

Nereis masolocensis GruBE, 1878, p. 75 , pl. 5, fig. 4.

The Albatross specimens corresponded exactly with these in respect to tooth structure. Grube states that 22 anterior somites are marked with a brown stripe on either side. In these not more than 17 or 18 were so marked. A prominent feature is a brown band across the entire dorsal surface of the second setigerous somite.

Collected at Bohuao; Varadero Harbor, Mindoro; Subic; Tava Island; San Miguel Harbor; Varadero Bay, Mindoro; "Electric light, July 20, 1908," station Ds403, Capitancillo Island, between Leyte and Cebu, 182 fathoms, green mud bottom.

\section{NEREIS PECTINIFERA Grube.}

Nereis pectinifera GruBe, 1878, p. 66, pl. 4, fig. 5 ; pl. 5 , fig. 5 .

Collected at Labuan Blanda Island.

\section{NEREIS TONGATABUENSIS McIntosh.}

Nereis tongatabuensis McINtosH, 1855 , p. 212, pl. 34, figs. $7,8,9$; pl. $16 a$, figs. $5,6,7$.

Collected at Nasugbu Luzon.

NEREIS (PLATYNEREIS) INTEGER, new species.

An epitokous form, characterized by an enormous development of the prostomium, so that the antennae are thrown to the rentral surface, all that is visible from above being the enormous eyes and the shovel-shaped prostomium (figs. 1 and 2 ).

Male.-The prostominm rounded, its margin entire, the portion anterior to the eyes being very thin and translucent. In some individuals the palps may be seen through this translucent region. The anterior eyes are the larger, and they are situated on the lateroventral portion of the head.

The dorsal tentacular cirrus (lost in the specimen figured) extended in other specimens to the eighth somite. The median cirri(fig. 1) are much shorter.

On the ventral surface (fig. 2) appear the flattened antennae, which normally hang at right angles to the prostomium, but are 
figured as if pressed against its lower surface. The large anterior eyes with their latero-ventrally directed lenses occupy a considerable part of the ventral surface. Posterior and ventral to these are the palps with their two portions nearly equal in size, hanging down so as to cover the sides of the mouth. While in the figire they are shown under slight pressure, their direction is only very slightly changed by it.

The jaws have each a large terminal and five smaller lateral teeth. I could discover no trace of paragraths.

The dorsal cirri of the first seven somites are enlarged, increasing successively in size until the seventh is reached (fig. 3 of the
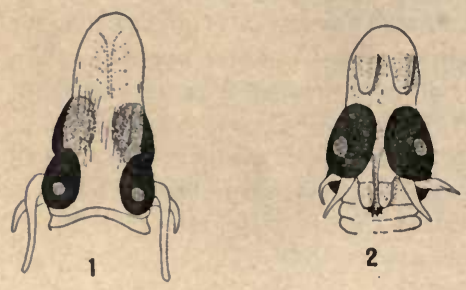

2

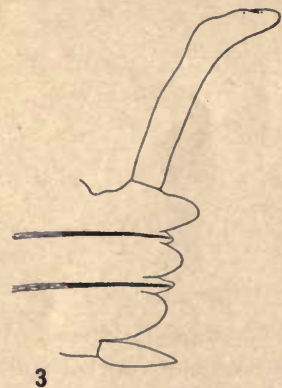

Figs, 1-4.-Nereis INTEger, 1, DORSAL View of HEAD $\times 22 ; 2$, VeNTiRAL VIEW OF HEAD $\times 22 ; 3$, 7 TI PARAPODIUM $\times 45 ; 4,8 T H$ PARAPODIUM $\times 45$. seventh). The notopodium has two obtuse subequal lobes, the acicula extending into a short conical lobe between them. The neuropodium has a dorsal conical lobe, into which the acicula extends, and an obtuse ventral lobe similar to that of the notopodium. Dorsal cirrus elongated. its terminal portion bent and slightly flattened as shown, somewhat foreshortened, in the figure.

Set a e of' notopodium with long "camerated" shafts, the terminal joint set into rather a deep socket. The terminal joint is long, slender, and very sharp pointed, with numerous very sharp teeth along the greater part of one edge. The teeth are all drawn out into fine processes, which bend apically so that each covers over several of those distal to it. In the ventral bundle are a few similar to the dorsal and others having the terminal portion short, narrow as compared with the basal joint, with one large tooth at the apex and a row of very fine teeth along one margin.

The parapodia, from eighth to fourteenth inclusive, are unmodified, though the general structure of neuropodium, notopodium, ventral cirri, and setae are essentially as in the seventh. The dorsal cirrus is much shorter and tapers slowly to a blunt end. 
The parapodial modifications begin on somite 15 . In a modified parapodium the neuropodium has a dorsal, and the notopodium a ventral sagittal lobe, which overlap, the notopodial being anterior. Dorsal to the slender dorsal cirrus is a broad rounded lobe with ventral to it, a lanceolate one extending to nearly the end of the cirrus. The ventral cirrus is much like the dorsal in form, but relatively a little heavier. Ventrally it carries a plate shaped like that of the dorsal but larger. Dorsally, attached to its base, this cirrus carries a zigzag three-pronged outgrowth, while on the ventral surface of the neuropodium is another outgrowth very similar to this but with four prongs. The setae are of the usual type with broad terminal joint toothed along one edge.

Most individuals show traces of brown spots on the dorsal surface. When best developed these appear in the anterior unmodified portion as prominent spots on the parapodia from the eighth to the fifteenth. In the modified portion there is a median dorsal and two lateral brown spots in each somite, with a double row of smaller brown spots on the dorsal surface of each parapodium. Ventrally these markings are most prominent in the modified region, where the median row breaks up into a double row of smaller spots and the parapodial row tend to coalesce into a single one.

In the collections were a number of females in the epitokous condition, but none which resembled the above-described males sufficiently to justify one in identifying them as of this species.

Collected from Subic Bay; Santa Cruz Harbor, Marinduque; San Miguel arbor, Ticao Island, a large number of individuals being from the latter locality; Port Matalvi, Luzon, and Romblon.

Type.-Cat. No. 18939, U.S.N.M., from latter locality.

\section{Family LEODICIDAE.}

Genus LEODICE Savigny.

\section{LEODICE APHRODITOIS Pallas.}

Eunice aphroditois PALLAS, 1766.-Ehlers, 1864-1868, p. 306, pl. 15, figs. 23-29.

Collected at Batan Island.

\section{Genus AGLAURIDES Ehlers.}

\section{AGLAURIDES FULGIDA Savigny.}

Aglaurides fulgida Savigny, 1820, p. 54.-Grube, 1878, p. 172.

Collected at station D5179.

Fragments of a Leodice were collected at station D5401, Tanguingui Island, north of Cebu, 30 fathoms, fine sand bottom. 


\section{Genus HYALINOECIA Malmgren.}

Fragments of a Hyalinoccia and numerous tubes were collected from the following localities. No individuals were well enough preserved to enable the species to be identified. D5654, Cape Tabako, Gulf of Boni, 805 fathoms. D5439, Hermana Mayor Light, West coast of Luzon, 940 fathoms, green mud bottom. D5209, Taratara Island, off western Samar, 20 fathoms, green mud. D5619, Mareh Island, Molueca Passage, 435 fathoms, fine gray sand bottom. D5132, Island off Panabutan Point, Sulu Sea, 26 fathoms, green mud and sand bottom. D5432, Corandagos Island, Eastern Palawan, 51 fathoms, sand bottom. D5187, Apo Island, Tanon Strait, 22.5 fathoms, soft green mud bottom. D5365, Cape Santiago Light, Balayan Bay, 214 fathoms. D5606, Dodepo Island, Gulf of Tomini, Celebes, 834 fathoms, green mud bottom. D5670, Chenoki Point. Macassar Strait, 1,181 fathoms, gray mud bottom. D5656, Olang Point, Gulf of Boni, 484 fathoms, gray mud bottom. D5126, Nogas Island, Sulu Sea, 742 fathoms, soft green mud. D5181, Antonia Island, off eastern Panay, 26 fathoms, mud and fine sand bottom. D5582, Si Amil Island, Darvel Bay, Borneo, 890 fathoms, gray mud and fine sand bottom.

\section{HYALINOECIA CAMIGUINA Grube.}

Hyalinoccia camiguina GruBE, 1878, p. 142, pl. 10, figs. 1, 1a, 1 .

While most of the specimens of this genus were represented by either the tubes alone or fragments of the animals, one lot from D5483, Cabugan Grande Island, between Samar and Leyte, 74 fathoms, sand and broken shell bottom, contained a number of wellpreserved individuals of this species. These were not easily removed from the tubes without injury, but all points in their external anatomy could be seen through the transparent tube.

\section{Family MALDANIDAE.}

\section{Genus MALDANE Grube.}

\section{MALDANE DISPARIDENTATA Moore.}

Maldane disparidentata Moone, 1904, p. 494, pl. 38, figs. 28-31.

A single specimen, retaining only about 12 of the anterior somites and two from somewhere neur the middle of the body, were collected at D5592, Silungan Island, Sibuko Bay, Borneo, 305 fathoms, green mud bottom. Fragments of the anterior ends of others were collected at D5207, Badian Island, Samar, 35 fathoms, green mud and 
sand bottom; and D5209, Taratara Island, Samar, 20 fathoms, green mud bottom. I have identified them as of this species from the form of the head and anterior somites and of the setae.

\section{MALDANE SARSII Malmgren.}

Maldane sarsii Malmgren, 1865, p. 18S.-ARWrdsson, 1906, p. 251, pl. 6, figs. 192-199; pl. 10, figs. 333-338.

In identifying these as sarsii I have followed Arwidsson's diagnosis of the species.

One entire specimen and some fragments in mud tubes taken from D5585, Sidipan Island, Sibuko Bay, Borneo, 476 fathoms, gray mud bottom. Another was from D5368, Tayabas Light, Verde Island Passage, 181 fathoms, gray mud bottom; and a fragment from 5533, Balicasag Island, between Cebu and Siquijor, 432 fathoms,. green mud and sand bottom.

\section{Family AMPHICTENIDAE.}

\section{Genus PECTINARIA Lamarck.}

\section{PECTINARIA Clava? Grube.}

Pcetinaria clava GRUBE, 1878, p. 212, pl. 11, fig. 3.

This I have doubtfully identified as of this species, as the specimens had dried and details of structure were difficult to make out.

Collected from station D5162, Tinagta Island, Tawi Tawi Group, 230 fathoms, coarse sand and broken shell bottom.

Part of a tube of pectinaria, species? was dredged at station D5206, Badian Island, Samar, 32 fathoms, green mud bottom.

\section{Family GLYCERIDAE. \\ Genus GLYCERA Savigny. \\ GLYCERA LONGIPINNIS Grube.}

Glycera longipinnis GrUBE, 1878, p. 1S2, pl. 8, fig. 9.

Station 5113, Sombrero Island, Luzon, 159 fathoms, dark green mud bottom.

\section{Family CHAETOPTERIDAE. \\ Genus PHYLLOCHAETOPTERUS Grube. \\ PHYLLOCHAETOPTERUS CLAPEREDII McIntosh.}

Phyllochaetopterus claperedii McINтоsн, 1855, p. 374, pl. 45, figs. 9,10 , $10 a, 11$; pl. 26 , fig. 1 ; pl. $24 a$, figs. $1-5$.

Tubes containing portions of the anterior ends of two specimens were collected at Station D5206, Badian Island, Samar, 32 fathoms, green mud bottom. Large numbers of tubes without any of the 
animals were collected at station D5382, Arena Point, Ragay Gulf, Luzon, 128 fathoms, mud bottom; and they were also found at D5209, Taratara Island, Samar, 20 fathoms, green mud bottom.

\section{Family TEREBELLIDAE. \\ Genus LOIMA Malmgren. \\ LOIMA MONTAGUI Grube.}

Terebella montagui Grube, 1878, p. 224, pl. 12, fig. 3.

Collected at Station D5160, Tinakta Island, Tawi Tawi Group, 12 fathoms, sand bottom.

\section{LOIMA ANNULIFILIS Grube.}

Terebclla annulifilis Grune, 1878, p. 225, pl. 13, fig. 2.

Two specimens were in the collection, one having lost all of its gills and on the other only fragments of these organs remained. Enough were present, however, to establish the diagnosis of the species, and they agreed in other respects with Grube's description.

Station 5209. Taratara Island, Samar, 20 fathoms, green mud bottom.

\section{Genus PISTA Malmgren.}

YISTA TYPHA Grube.

Pista typha GrUBe, 1878, p. 232, pl. 12, fig. 4.

Collected at Stations 5428, 30th of June Island, Palawan, 1,105 fathoms, gray mud bottom; and D5209, Taratara Island, Samar, 20 fathoms, green mud bottom.

\section{Family CAPITELLIDAE.}

\section{Genus DASYBRANCHUS Grube.}

DASYBRANCHUS UMBRINUS Grube.

Dasybranchus umbrinus Grone, 1978, p. 189.

Collected at D5372, Tayabas Light, Marinduque Island, green mua bottom.

\section{Family SABELLIDAE. \\ Genus SABELLA Linnaeus. \\ SABELLA SPECTABILIS Grube.}

Sabclla spectabilis GrUBE, 1878, p. 253, pl. 14, flg. 4.

Two bottles containing this species. One was labeled $\mathbf{1 4 5} 21$, F2599, and the other A4371, F.2542.

Tubes of a sabellid were collected from D5213, Destacado Island, east of Masbate Island, 80 fathoms, sand, mud, and shell bottom; 
$5300,20^{\circ} 31^{\prime}$ N.; $115^{\circ} 49^{\prime}$ E., 265 fathoms, gray mud and sand bottom; and D5̆411, Lauis Point, between Cebu and Bohol, 145 fathoms, green mud bottom.

\section{Family SERPULIDAE.}

\section{Genus SERPULA Linnaeus. \\ SERPULA (POMATOSTEGUS) ACTINOCERAS Mörch.}

Pomatostegus actinoceras МöвcH, 1863, p. 54, pl. 11, fig. 16. This reference quoted from Grube, 1878, p. 271.

Station 5205, Leyte, staghorn coral and rock bottom. Caguayan Point.

Empty serpulid tubes were collected from D5413, Lauis Point Light, Dupon Bay, 42 fathoms.

\section{BIBLIOGRAPHY.}

Arwidsson, I.

1906. Skandinavische und arktische Maldanidae. Zoolog. Jahrbücher,

Suppl. 9, Hft. 1, pp. 1-308, pls. 1-12.

Atdour, J. V., and MrLxe-Edwakds, $\mathrm{H}$.

1832-1834. Recherches pour servir â l'histoire naturelle du littoral de la

France. Paris, 2 vols., $1 \mathrm{~S}$ pls.

Chamberlin, R. V.

1919. The Annelida Polychaeta. Reports on an Exploration off the

West Coasts of Mexico, Central and South America, and off the

Galapagos Islands, In charge of Alexander Agassiz by the U. S. Fish

Commission steamer Albatross during 1891, Lieut. Commander Z. L.

Tanner, U. S. N., commanding, No. 38. Reports on the Scientific Results of the Expedition to the Tropical Pacific in charge of Alexander Agassiz, by the U. S. Fish Commission steamer Albatross, from August, 1909, to March, 1909, Commander Jefferson F. Moser, U. S. N., commanding, No. 20. Reports on the Scientific Results of the Expedition to the Eastern Tropical Pacific in charge of Alexander Agassiz by the U. S. Fish Commission steamer Albatross from October, 1904, to March, 1905, Lieut. Commander L. M. Garrett, U. S. N., commanding, No. 31. Memoirs of the Museum Comparative Zoology at Harvard University. Cambridge. Vol. 48,514 pp., 80 pls.

Ehlers, E.

1864-1868. Die -Borstenwürmer (Annelida chaetopoda) nach systematischen und anatomischen Untersuchungen dargestellt. Leipzig. Grube, E.

1878. Annulata Semperiana. Beiträge zur Kenntniss der Aunelidenfauna der Philippinen nach den von Prof. Semper mitgebrachten Sammlungen. Mém. Acad. Sci. St. Pétersbourg, vol. 25 , ix +300 pp., 15 pls.

KINBERG, J. G. H.

1857. Ofvers. of K. Vet. Akad. Forh.

LEVINSEN, G. M. R.

1886. Kara-Havets, Copenhagen.

McINTosh, W. C.

1885. Report on the Annelida Polychaeta collected by H. M. S. Challenger during the years 1873-1S76. Zoology, vol. 12, 554 pp., pls. 1-55; 1a-39a. 
MaLmgren, A. J.

1865. Nordisker Hafs-annulater. Ofv. K. Vet. Akad. Forh Stockholm, vol. 22 , pp. $61-110 ; 181-192 ; 355-410$; pls. $8-15 ; 18-29$.

М̈̈всн, O. А. L.

1863. Revisio critica Serpulidarum.

Moore, J. Percy,

1904. New Polychaeta from California. Proc. Acad. Nat. Sci. Philadelphia, vol. 56 , pp. $484-583$, pls. 37,38 .

de Quatrefages, A.

1865. Histoires naturelles des annelés marins et d'eau douce.

- Pallas, P. S.

1766. Miscellanea Zoologica. 224 pp., 14 pls.

SAVIGNY, J. C.

1820. Système des Annélides, principalement de celles des côtes de l'îgypte et de la Syrie.

Treadwell, A: L.

1906. Polychaetous Annelids of the Hawaiian Islands, collected by the steamer Albatross in 1902. Bulletin of the U. S. Fish Commission for 1903 , vol. 23 , pp. $1145-1181,81$ figs. in text.

\section{()}




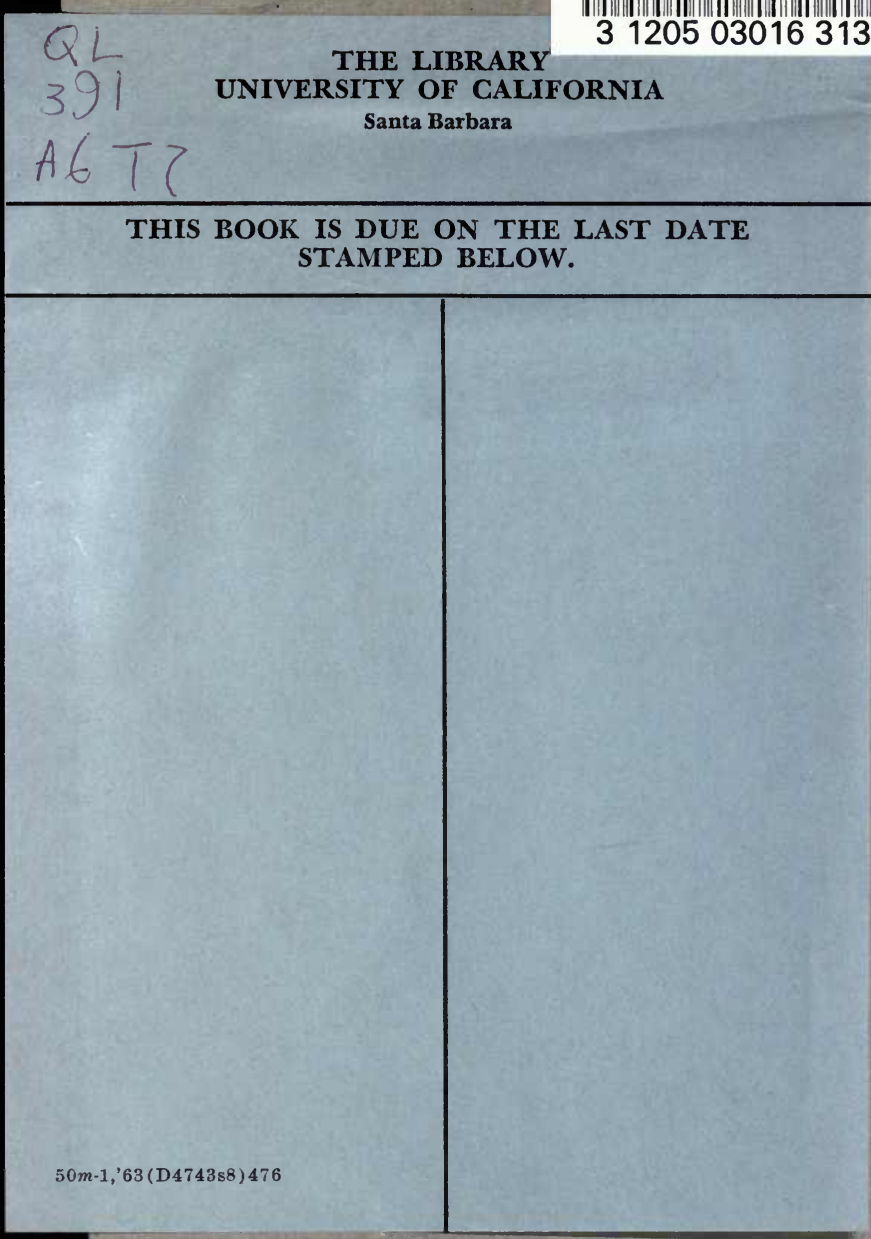


